\title{
WORLD WAR I AND PROPAGANDA POSTER ART: COMPARING THE UNITED STATES AND GERMAN CASES
}

Joseph Joe Kaminski*

\begin{abstract}
This paper looks at some similarities and differences between propaganda art used by Germany and the United States during World War I. The first section briefly looks at aesthetic theory and addresses the philosophical question of whether war propaganda posters are, in fact, 'art' at all. Then images of various posters that were popular and widely published by both nations are shown and discussed. This paper concludes that while there are many thematic similarities between the posters used by both sides, there are also some important differences. The most obvious difference between the German and American propaganda art was in regard to the overall tone of the posters and the colors used in the presentation. The images used have been downloaded from a reputable website that depicts reproductions of the posters that were used during WW1. Understanding the nature of the propaganda used by each side can help shed light on the attitudes and sentiments towards the war held by political elites and citizens alike.
\end{abstract}

Keywords: Propaganda Art; Uncle Sam; Social Mobilization; World War I; Aesthetic Theory; Theodor Adorno and Immanuel Kant

\section{Introduction}

World War I saw a major shift in the way warfare was carried out at many different levels. Most notably, it ushered in a new form of mechanized form of warfare previously unknown in the world. While the war began with similar technology and military tactics as utilized in $19^{\text {th }}$ century warfare, by the end of the war, telephones, wireless communications, armored tanks, and even airplanes would be utilized by all sides involved. (Hartcup, 1988) In regards to the harsh realities of the new mechanized warfare of World War I, Ernst Jünger's monumental literary effort, Storm of Steel, explains the confusion and fear of those troops in his battalion after their first time being attacked;

War had shown its claws, and stripped off its mask of cosiness [sic]. It was all so strange, so impersonal. We had barely begun to think about the enemy, that mysterious, treacherous being somewhere. This event, so far beyond anything we had experienced, made such a powerful impression on us that it was difficult to understand what had happened. It was like a ghostly manifestation in broad daylight. (Jünger, 2003: 7)

War was now total and entire nation states were involved. Along with the transformation of the way war was conducted on the ground, WWI was also represented *Corresponding author: Joseph Joe Kaminski, Assist. Prof. Dr. at Social and Political Sciences, International University of Sarajevo, Bosnia and Herzegovina, e-mail: jkaminski@ius.edu.ba. 
a shift in the way the 'war for public support' was fought. The use of propaganda art was essential in galvanizing opinions and reshaping ideas during WWI. (DeBauche, 1997; Latham, 2006, and Tunc, 2012) Both the Central Powers and Allied Powers used propaganda to encourage citizens to not only join the army, but to also engage in certain desirable social behaviors at home that to assist in the war effort such as purchasing war bonds and conserving food and other physical resources. In this paper I will compare and contrast the different styles seen in allied propaganda as opposed to German propaganda.

\section{The Function of War Propaganda Art - Is it Really Art at All?}

The essential thing to understand about war propaganda art is that it seeks to appeal to emotion over reason. In the case of World War I, it was meant to be approachable and understandable. According to Chambers,

The function of posters was to inform, instruct, or suggest new ways of looking at the war. Their central ideas had either to correspond to the mentality and ideas of the viewer, or had to manipulate his ideas in a positive or negative manner. The idea or message had to be easily comprehended by the target audience. Its appeal was more emotional than rational. (Chambers, 1984: 54)

Richard Chambers (1983) offers 3 main area of content that are commonly utilized in war propaganda posters. Below is a chart outlining these 3 main areas;

\section{Chambers 3 main areas of War Propaganda Art}

1. Appeals to patriotism and valor in order to motivate an individual(s) to contribute to the war effort by joining the military.

2. Appeals to civilian-orientated activities, emphasizing the civilian/military inter relationship. This relationship includes the production of war materials, the incorporation of women into the work force, and/or campaigns to collect funds to finance the war.

3. Appeals to fear, specifically via the demonization of the enemy. These appeals often contain 'horror and atrocity' images in an effort to instill hate and fear for the enemy in the minds and hearts of citizens. (Chambers, 1983)

From a theoretical perspective on the function of art, Chambers explanation of what is essential in war propaganda art stands in opposition to the view articulated by the influential art and cultural critic, Theodor Adorno on the function and role of art.

Adorno was a part of a generation of Jewish intellectual émigrés who escaped Nazi Germany during WWII. Most of these critics steeped their critiques of the fine arts within a specific type of cultural Marxism. (Houston, 2012) This movement would later come to be known as Western Marxism, because it consciously divorced itself from the political and cultural orbit of the Soviet Union. According to Doug Kellner,

The term "Western Marxism" was first used by Soviet Communists to 
disparage the turn to more Hegelian and critical forms of Marxism in Western Europe, but it was soon adopted by thinkers like [Georg] Lukács and [Karl] Korsch to describe a more independent and critical Marxism from the party and "scientific" Marxism of the Second and Third Internationals. (Kellner, 2005: 155)

At the core of the Western Marxist analysis of art was the recognition of the central role social and economic conditions play in the construction of any work of art. This is to suggest each work of art is unique in the sense that it could only be completed within the specific spatial-temporal location it was created in. For example, it would be impossible to assume Leonard Da Vinci's, Mona Lisa, could have been created 300 years earlier or 300 years later than it was; its creation was a direct result of the social and economic conditions the artist himself was living in. The same can be said for other high works of art. Within this view, each work of art truly is a unique and original creation.

At the crux of Adorno's argument was that authentic arts' primary function was to raise critical/radical revolutionary consciousness amongst its viewers. This helps explain why many members of the Frankfurt School admired artists like Russian artist Wassily Kandinsky and atonal composers like Alban Berg and Arnold Schönberg. These artists all experimented with new artistic forms that were meant to be revolutionary in both form and content.

As mentioned previously, rather than war propaganda art appealing to an individual's higher intellectual and emotional reflexive capacities, it instead was meant to appeal to the most base and easily accessible emotions. While at the most basic level, propaganda art is concerned with raising some type of consciousness (most certainly not revolutionary), its primary concern was with appeals to raw emotion rather than one's rational reflexive capacities. Hence within war propaganda art there exist common leitmotifs in many WWI propaganda posters; these include patriotism and unquestioning loyalty to the regime. This will be further explored in the next couple sections of this paper.

Theodor Adorno wrote extensively on the function of art and music. Adorno's view on art and music was similar to John Dewey, William James, and cultural Marxists like Walter Benjamin and Siegfried Kracauer, who saw both art and music as inextricably connected to its immediate culture context. (Kerr, 2012) Like the other Western Marxists, Adorno believed that a work of art's meaning was not objectively universal like Kant did; rather meaning and value was contingent upon the historical circumstances surrounding a work of art and the subjective position of the viewer of the work itself. In Adorno's words, "Since time immemorial, human reactions to artworks have been mediated to their utmost and do not refer immediately to the object; indeed they are now mediated by society as a whole (Adorno, 2004: 299)." Not only does the individual's location in space and time 
viewing the work of art influence a particular work of arts meaning, but the overall pulse of society does as well.

Adorno's approach to aesthetic theory differed from the earlier aesthetic theory offered by Kant which posited that within each work of art was a unique objective truth that existed independent of the viewer or interpreter of the work of art. According to Murray Skees,

The autonomy of art for Kant lies, then, in both the aesthetic judgment of the beautiful object and, in the case of art, the artist's creation of that work of art as well. In the first instance, the judgment is autonomous in that it does not presuppose or depend upon the object's utility or purpose, but in the pleasure of the contemplative attitude that we take towards the work of art. (Skees, 2011: 920)

Where war propaganda art most radically differs from traditional forms of art for the likes of Adorno is the function it plays in reaffirming the prevailing attitudes and values of the state. Rather than war propaganda art acting as a subjective critique of reified social structures and the apparatus of the repressive state itself, war propaganda art seeks to reinforce traditional orthodoxy within the state. In this regard, it is quite reasonable to assume within the framework of critical theorists like Adorno and Kracauer, propaganda 'art' is not actually 'art' at all since true art serves some type of liberating and revolutionary function; art is meant to challenge the state, not reaffirm its prevailing norms, values, and institutions.

Moving beyond the philosophical discussion on what constitutes art, the fact remains that World War I propaganda posters were a widespread historical phenomenon. They were viewed and interpreted by millions of people across the world. To deny their importance and role in the shaping of attitudes and values would be a serious mistake. Understanding the images and themes covered in WWI propaganda art can shed light on the attitudes of those living during this time period towards their own nation and the war in general.

\section{The United States and World War I Propaganda Art}

The United States sought to stay out of WWI as long as it could. However, the sinking of the Lusitania in 1915, in which 1,198 innocent passengers died, was really the very public incident necessary in the eyes of most historians that ultimately forced the Americans into war. (Jones, 2001) According to Howard Jones, the popular American publication, The Nation, stated, the sinking of the Lusitania was, "a deed for which a Hun would blush, a Turk be ashamed, and a Barbary pirate apologize (Jones, 2001: 73)." 128 of 139 American passengers died in the unprovoked attack. 
Despite the fact the US did not formally enter the war until 1917, the Wilson administration began promoting the use of propaganda as early as 1914 when the war began. "Even though the United States had remained neutral until 1917, it had begun using the 'power of suggestion' through mass communication in 1914 with its negative portrayal of the 'rape of Belgium', and in 1915 with the yellow journalism associated with the Lusitania incident (Tunc, 2012: 195)." The Wilson administration went as far as creating a 'Committee on Public Information,' that not only strategically placed advertisements in newspapers and magazines, but went as far as encouraging US filmmakers to make movies demonizing the German state. (DeBauche, 1997, and Latham, 2006) Two such anti-German films that came out around the time of WWI were, The Kaiser: The Beast of Berlin (1918) and The Prussian Cur (1919).

As the US entered the war, along with building up the war effort in the sense of artillery and tanks, the US needed to desperately win support from the mass publics. Many American's were initially opposed to getting involved in the war for numerous reasons. According to Jeanette Keith, sentiment for neutrality was strong among church leaders and certain immigrant communities in the United States, including Irish Americans, German Americans and Swedish Americans. (Keith, 2004) The propaganda apparatus needed to somehow address all the grievances against engaging in WWI while at the same time not making the situation sound so dire as to foster even more negative sentiment towards the war. Much of the propaganda artwork of WWI sought to highlight positive American themes. The imagery below demonstrates some of the major themes covered in WWI propaganda art. ${ }^{1}$

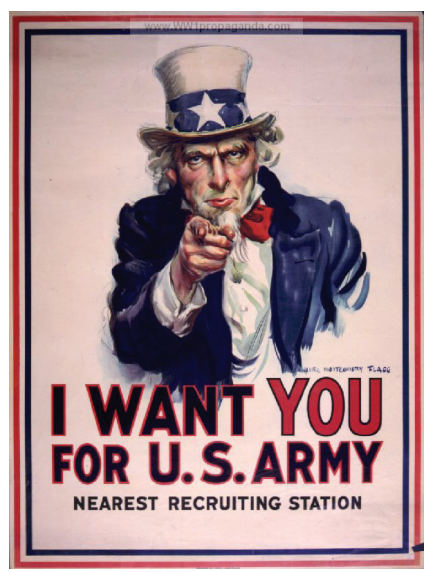

Uncle Sam: I want YOU for the US Army portrays the classic image of Uncle Sam. In this image we see a tough looking-elderly, bearded white male, dressed patriotically, affirmatively pointing at the viewer. In this iconic image that to this day is revered in 1All of the American WWI posters mentioned in this article can be found at http://www.wwlpropaganda.com/world-war-1-posters/american-ww1-propaganda-posters. All German WW1 posters mentioned in this article can be found at, http://www.ww1 propaganda.com/world-war-1-posters/german-ww1-propaganda-posters 
Americana, and American folklore, Uncle Sam is admonishing young men to join the U.S. army. 'Uncle Sam' is a character that often is used to personify the US Government. For example, a phrase commonly used in the United States is, 'I owe money to Uncle Sam,' which means one owes taxes to the United States Government. Uncle Sam is mentioned in the British folk song mocking the rag-tag US Revolutionary Army, 'Yankee Doodle' in 1775. (Lossing, 1850) However, reports of 'Uncle Sam' have dated back to the $1^{\text {st }}$ half of the $18^{\text {th }}$ century and the creation of the United States.

The creator of the iconic 'Uncle Sam' image is credited to the popular American political illustrator James Montgomery Flagg (1877-1960). Flagg's portrayal of Uncle Sam was first published on the cover of the magazine Leslie's Weekly, on July 6, 1916, with the caption, "What Are You Doing for Preparedness?" (Library of Congress Archives) The poster, Boys and Girls! You can Help Uncle Sam win the War, also contains a variation of Uncle Sam. This time he appears in a much friendlier and more approachable form; a young girl is sitting on his lap and a young boy is listening intently. This particular poster is an appeal for the youth to save their money and buy war savings stamps. The tone is hopeful; a personal appeal is made to the reader of this poster that they do not have to directly engage in overseas combat to help the US win the war; instead simply supporting the war effort financially can make a difference. This means that all American's can get involved, not just those who are young, healthy, and male. One can be an 85 year old woman who is deaf and blind and still be a part of the victory. The theme of inclusivity can be noted in much of the US propaganda used throughout the war. The role of children in the US war effort will be further discussed in the next few pages.

The Woman's Land Army of America poster emphasizes the role of women in the US war effort. One of the more common themes in American WWI posters is that of the role citizens who are not directly in combat can play in the war effort. Middle-class, progressive urban women were a major part of the mobilization effort.

With the assistance of mostly middle-class urban Progressive women, Hoover [in charge of the Land Army of America at the time] was able to recast rural values as a panacea to wartime problems by promoting war gardening, or victory gardens, as a means of involving civilians in the war effort and lessening the load on the US manufacturing system. (Tunc, 2012: 199)

Once again, one immediately notices bright colors used in this poster. Two women can be seen working together to haul a large wooden basket filled to the brim with freshly gathered fruits and vegetables. Behind the two women carrying the heavy load of produce, is a woman gallantly riding on a horse, holding a large American flag. The American flag is placed in the center of the poster, reminding the viewer of patriotic themes. 
The heroic efforts of women during WWI showed the world that women had the ability to take on essential roles in public life. (Dumenil, 2002, and Adie, 2013) According to Dumenil, "For many women, the war effort offered opportunities for volunteer service to the nation that also provided the personal satisfaction of fulfilling, meaningful work, even though it was unpaid labor. For others, the war provided new, though often temporary, employment options (Dumenil, 2002: 36-37)." The women who volunteered for service learned many important trade skills such as carpentry, farming, and metal work.

Women were not allowed to fight in the US Military during WWI and most were expected to keep things functioning smoothly back at home. (Tunc, 2012) The US government invested in the creation of numerous different posters emphasizing the importance of land management and farming during WWI. Since many of the men who were farmers were off at war, the women left behind were needed to keep the farms running. Many women at the time did not have the same knowledge as their husbands of modern farming techniques. As a result, the US government offered courses to teach them the skills needed to keep food production high. The Woman's Land Army of America encourages women to take courses at the University of Virginia to learn modern farming techniques. One notices the tuition for the 2 week course was free and that board was only $\$ 5$ a week. The US needed constant food production in order to keep the soldiers properly fed and the economy at home strong.

Despite the efforts to include women in the war effort, the poster's themselves still reinforced gender stereotypes and did not accurately portray the demographic realities in the US at the time. "War posters were far from accurate in their depiction of American women. The images were white and the messages for the most part reinforced conventional gender stereotypes. The emphasis was on female service and self-sacrifice (Dumenil, 2002: 36-37)." Images of black, Asian, and Hispanic women are not seen in most US war posters. The emphasis on service and sacrifice also was applied to the case of children in US war posters.

Lest we perish Campaign for \$30,000,000; American Committee for Relief in the Near East; Armenia-Greece-Syria-Persia, is another example of a poster that utilizes the feminine form to convey its message. This particular poster is an appeal to Americans once again to reach deep into their pockets and give money towards US interests in the war effort. This particular poster is a call for, $\$ 30,000,000$, an enormous amount of money in the 1910's. A simple purchasing power calculator would calculate the relative value of $\$ 30,000,000$ around 1914 to $\$ 721,000,000$ today. This image does not actually spell out how the money is going to be used other than calling it relief in the near east. During WWI, Armenia, Greece, Syria, and Persia were seen as allies. The situation of these nations was dire. According to a congressional report in 1918, "The largest part of the funds contributed for relief goes to these orphanages. Letters are constantly being

Epiphany: Journal of Transdisciplinary Studies, Vol. 7. No. 2, (2014) (C) Faculty of Arts and Social Sciences 
received in order that the number of orphans be increased (Fowle, Gates, et. al, 1918: 10)."

The image shows a young, fair skinned woman, who clearly is of Mediterranean or Persian descent with her arms outstretched asking for help from the Americans. Nonsexually provocative images of regular housewives, Lady Columbia, and the Statue of Liberty were commonly used to promote food related programs, whereas more sexually provocative images of beautiful, youthful women were used to sell war bonds, raise cash directly, and encourage men to join the service in the United States. (Stanley, 1983, and Banta, 1987) If one looks closely, the woman is wearing some type of head covering. However, it is being worn in a way that would not be too foreign to the American public as to be alienating. The colors are simpler in this poster than in other ones, however one cannot help but be drawn to the red scarf in the picture as a focal point.

Helping Hoover in our U.S. School Garden is a poster that refers to a government program that was created with the passage of the 1914 Smith-Lever Act, also commonly referred to as the Agricultural Extension Act. The Smith-Lever Act established a system of cooperative extension services that were connected to the land-grant universities. The goal of the new system of cooperative extension services was to inform people about the most contemporary developments in agriculture, home economics, public policy/ government, leadership, 4-H, economic development, and coastal issues.

The Smith-Lever Act also gave President Woodrow Wilson the authority to appoint future US president Herbert Hoover to a new government agency that sought to prevent food shortages and price inflation which could have threatened the entire war effort. Hoover and Wilson had to toe a fine line; while they needed to encourage rationing and frugality, they did not want to appear as 'socialists' by forcing American's to ration. According to Tunc, based on these realities, "Hoover thus had to convince Americans to self-regulate their consumption of food voluntarily, and realized that playing on patriotic sentiments would be the easiest, and quickest, way to do so (Tunc, 2012: 197)." As a result of slick advertising and posters, Hoover's program quickly gained popularity amongst Americans everywhere. Hoover made specific efforts to encourage women to participate in the food rationing program. (Gordon, 1999, and Kingsbury, 2008) This would explain the use of happy, wholesome, 'All-American' Caucasian children in food preservation posters and similar WWI advertising campaigns.

Despite most US posters being more upbeat in general, there were some exceptions. The final American example explored in this article is the ominous poster; We've fought in the open bubonic plague, yellow fever, tuberculosis: Now venereal diseases. This poster shows that sexually transmitted diseases (STD's) had been a concern of various armies prior to WW1. During the mid $19^{\text {th }}$ century, the British passed laws regulating prostitution that were ultimately unsuccessful. Despite laws being enacted in the mid 1860's, by 1895 , 
STD's were at a peak amongst British military men. (Harrison, 1995) The United States had its own problems with venereal diseases during the Philippines-American War which lasted from 1899-1902, just prior to the outbreak if WWI.

The US Military and State Department set up commissions that sought to monitor and quarantine Filipino women who were thought to be infected with sexually transmitted diseases. Males who contracted STD's were looked at by the commanders in charge as morally flawed. "[...] they [the US military commanders] made the act of contraction a sort of bodily treason, a partial denial of one's physical constitution to the state (Kramer, 2011: 3)." During WW1 sexually transmitted diseases were of particular danger to soldiers. Having an STD coupled with the filthy conditions of trench warfare could become deadly in a very short time after contracting the disease(s).

This poster also references previous ailments that most American would be familiar with that have caused mass deaths such as the bubonic plague, yellow fever, and tuberculosis. Each of these previous plagues is represented by one of the 3 skeletons standing behind the demon woman, who represents the new danger, venereal diseases. In the first decade of the $20^{\text {th }}$ century, over 100,000 American's died each year of the decade from tuberculosis, also known as 'consumption' and 'the White Plague (Lochimescu and Tomford, 2014). The word 'tuberculosis' on the poster would most certainly raise immediate attention to the viewer living the 1910's who very likely knew someone who died of this terrible disease. The mention of bubonic plague would also resonate with most American's who were most certainly taught about how it killed approximately $1 / 3$ of the European population in 1347AD in a world history class in grade school.

The colors in this poster are much darker. The image of skeletons and semi-naked demon women, representing lust and fornication, holding a chained eagle or vulture standing on a skull were meant to both shock and raise fear inside the viewer. While it appears that the bird used in this image is a vulture, upon first glance one could easily think it might be some type of eagle. This is important for historical and cultural reasons within the US.

The bald eagle has been the symbol of American 'democracy and freedom' almost since America's inception. The founding fathers of the US like to compare the new nation to the Roman Empire. The use of the Eagle was common in the Roman Empire, thus the founding fathers chose the Bald Eagle as the main symbol that appears on the Great Seal of the United States. (Lawrence, 1990) While at this point in history it may be impossible, it would be interesting to find out if the choice of the 'bald eagle-looking' bird being chained to the demon woman, standing on top of a skull was intentional. The poster is saying that lust and sexually transmitted diseases are enthralling American's and the future of America in general. 


\section{Germany and World War I Propaganda Art}

Following the assassination of Archduke Franz Ferdinand of the Austro-Hungarian Monarchy by a Serbian nationalist, the reeling Austro-Hungarian Empire declared war on Serbia. Following this declaration, a German response was imminent, especially considering the long historical ties between the two states directly linked to the powerful Habsburg Dynasty. For a long time, what was called, the 'spirit of 1914' hypothesis argued that German's were almost unanimously excited about the prospect of war. This went largely unquestioned by academics for decades. This hypothesis was bolstered by the fact that every party in the Reichstag voted in favor of entering the war, even traditionally anti-war Socialists. However in the past 20-30 years new scholarship has emerged challenging that axiom.

In 2000, Jeffrey Verhey published, The Spirit of 1914: Militarism, Myth, and Mobilization in Germany (Cambridge, 2000), which argued that, similarly to their American counterparts, German's held mixed feelings on whether to enter the war or not. On the 'spirit of 1914' hypothesis, Verhey states, 'Indeed, given the myth-makers' intentions, it is not surprising that their myth of the 'spirit of 1914,' an account of the history of German public opinion in July and August 1914, became increasingly more removed from its real history (Verhey, 2000: 9)." For Verhey this myth was perpetuated by conservatives who sought to romanticize the war and foster national pride and a sense of ethnic solidarity. Verhey's argument makes sense considering the fact that the Germans went to such great efforts to produce highly visible war propaganda posters. If the German public truly were 'unanimous,' as the spirit of 1914 hypothesis suggests, why would such efforts be made to convince the public, via propaganda to support the war effort?

From the very beginning of WWI, the German state already had multiple agencies in charge of disseminating propaganda.

Official German propaganda at the outbreak of the war was conducted by the press bureau of the imperial foreign office, the public relations officers of the army and navy intelligence services, the affiliated telegraph agencies, and certain foreign press bureaus. (Lutz, 1933: 498)

The German poster, Kriegsanleihe, helft den Hütern eures Glückes, makes an appeal to the family, and more specifically, traditional German family life. One cannot help but notice the sword that the muscular young father is holding as he caresses his wife's should and newborn baby's back. Another interesting thing to observe in this poster is the exaggerated size of father's hand that is caressing his wife and baby. Exaggerated masculinity permeates much of the propaganda posters utilized by the Germans during WWI. The text says, "War loans help the guardians of your happiness." We can see an appeal to patriotism and the duty of the citizen in this particular image. 
The highly patriarchal nature of the German family was explored in detail by the prominent Frankfurt School scholar Eric Fromm in his book, The Working Class in Weimar Germany: A Psychological and Sociological Study (Harvard Press, 1984). The research for this work began in 1929 at the now legendary Institute of Social Research (Institut für Sozialforschung) at Frankfurt-au-Maim, the namesake of what would become known as the Frankfurt School of thought.

Even though this project began prior to the rise of Hitler, it remained unpublished until the 1980's. Fromm's findings were based on a 271 open ended questionnaire that he used qualitative and quantitative techniques to evaluate. In this work, Fromm concludes that there is an inherent authoritarianism, specifically within the working class German family, that ultimately facilitated to the rise of Hitler and the politics of the $3^{\text {rd }}$ Reich. (Fromm, 1984) While at first many of those being questioned in the survey expressed less reactionary views, after utilizing less overtly-political and more opaque questioning, even those who initially expressed leftist political belief systems, revealed themselves to possess many of the same reactionary attitudes towards contemporary social norms and mores as those on the right and even extreme right possessed.

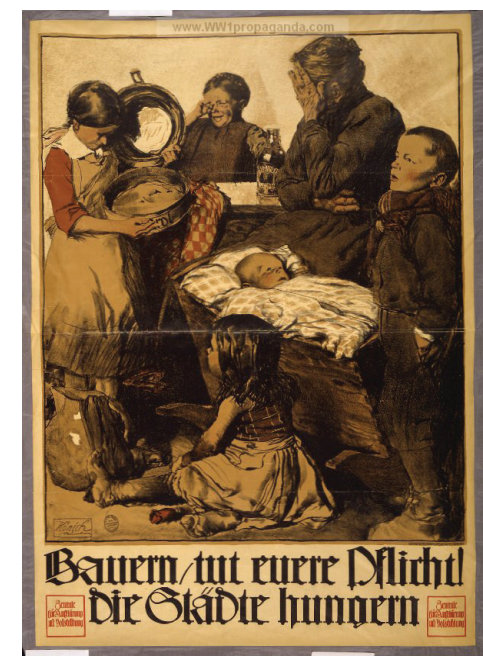

In another powerful appeal to German patriotism, Bauern, tut eurer Pflicht! Die Städte hungern, portrays a desperate looking German family. If one looks closely, the will notice the faces of the mother and older child in the back both appear to be in crying. Once again, we see a simple, powerful image that appeals to the basest emotions of the 'true German patriot.' As mentioned above the German propaganda apparatus framed the war as a defensive effort in which victory was certain. According to Ralph Lutz in 1933;

All these [state sponsored German] publications throw light on the chief themes of the home propaganda, which were: the war of self-defense against the encircling policy of the Entente, the certainty of victory and the consequent necessity of fortitude, the violations of the laws of land 
and naval warfare by all the enemies, the historic mission and high culture of Germans, the need for national expansion, and the proclamation that a German victory would be for the good of the world. (Lutz, 1933: 500)

The self-aggrandizement of German culture and its contributions to world culture, more specifically the belief in the unique role of German culture in spiritual world development, or what G.W.F Hegel called, Geist, would be an even more prominent theme during the reign of the $3^{\text {rd }}$ Reich. The need for national expansion was transformed into an all encompassing ideology in WWII. The notion of lebensraum, or that of 'living space' for Germanic peoples was canonized as not only an ideology, but a scientific law of nature; those peoples who are superior have not only a right, but a duty to conquer less civilized people. (Lee, 2003) This image does an effective job of showing how 'cramped' and 'uncomfortable' the German family is, and how without territorial expansion, it would be doomed.

The Germans also used images of women to promote the war effort. This image in many ways is similar to the American images of females patriotically contributing to the general war effort. Weichnachts Sammlung des bayerischen Roten Kreuzes für die Feldgrauen shows a young, physically fit German female pulling a sleigh, handing a bundle of provisions to a male German soldier. One's attention is immediately drawn to the bright gold and pink colors in the woman's dress. She has a determined and confident look on her face. If one looks really closely the will notice that the female is significantly smaller and frailer than the tall, burly male soldier. This is another example of the exaggeration of masculinity that can be seen in German propaganda.

The overall larger-scale, long term, sociological ramifications for German women were also similar to American women during the war; continued reinforcement of certain gender stereotypes, exploitation at the hands of male workers, limited upward career mobility, and no real concrete progress in gaining rights. In the words of Ute Daniel, the war in Germany was nothing more than, "an emancipation on loan (Daniel, 1997: 283)." The biggest outcome of WWI in regards to women in Germany was the 'horizontal' shifting of working women from one sector to another. (Daniel, 1997) Women in Germany were also under extra scrutiny if they engaged in adultery or prostitution. Despite the fact that any sexual encounter requires two people, the female participants in extra-marital liaisons with male soldiers were demonized by the state and public as being unpatriotic and of poor moral character, while the male participants, though discouraged by those in command, largely got a free pass. 


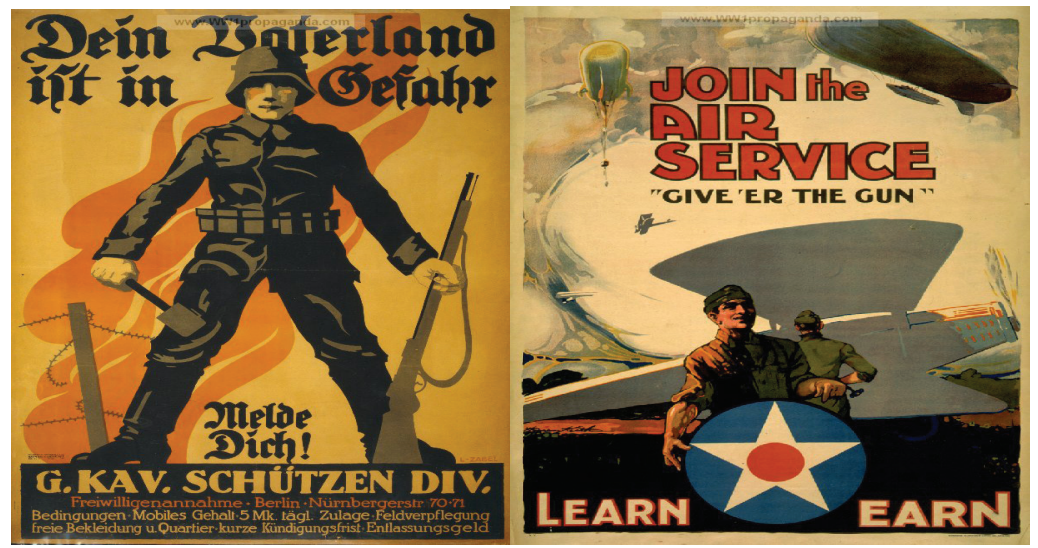

Dein Vaterland ist in Gefahr, melde dich! \& Join the Air Service: "Give 'er the Gun, " offer a side by side comparison of a German recruitment poster and an American recruitment poster. The poster on the left shows a German soldier with a rifle in one hand and fire and barbed wire behind him. The message is simple. Like the previous images, one sees appeals to patriotism and heroism. The words written are bold and clear; dein vaterland ist in gefahr melde dich, which translates into English as "Your fatherland is in danger." Anyone with even the most minimal patriotic tendencies would understand the meaning of this poster. Like the previous image, this is meant to appeal to raw emotion. The desperation can be readily felt in this particular poster. The world is literally on fire and the brave German soldier is the only thing that can save Dein Vaterland.

Unlike the darker imagery coupled with an appeal to selfless patriotism as seen in, Dein Vaterland ist in Gefahr, melde dich!, the American poster utilizes brighter colors, offers an appeal to personal gain, and shows a similar young recruit, except this one with a big smile on his face. 'Learn' and 'Earn' are meant to appeal to the individual's selfcentered interests of learning a useful skill and making money so they can live comfortable after the war. The entrepreneurial theme has long been a staple of American efforts to get people to join the services. Even today, one can regularly see commercials on American television that talk about the immediate financial and educational benefits of being a new enlistee in the US Armed Forces.

Going back to Chambers rubric, thus far we have appeals to patriotism and the family in the German World War I Propaganda posters, but we have yet to see the $3^{\text {rd }}$ element; that of demonizing the enemy being fought on the ground or scenes of violence or carnage. Bolschewismus heisst die Welt im Blut ersäufen references a specific ideological thereat as opposed to a specific physical military force such as the British or Americans. The ideological threat to German culture that is often repeated in German propaganda art is that of Bolshevism. The words on the poster translate in English to, "Bolshevism means the world will drown in blood." 
Indeed, German Nationalists and Social Democrats alike were already concerned with the rise Bolshevism in Russia before Lenin ever assumed formal power. In 1918, Social Democratic Party of Germany (Sozialdemokratische Partei Deutschlands) member and future Prime Minister of Prussia from 1920-1932, Otto Braun, argued that socialism must be achieved via democratic means and not through violence, and that since the Bolshevik revolution in Russia had become so violent, the German left must make it clear that Bolshevism and German socialism were not one in the same. (Schulze, 1982) The Bolsheviks were seen by many wealthier Germans as dangerous Atheist Jewish radicals whose national loyalty could not be trusted, and whose goal was to destroy civilization as they have come to know it. Here we can see the image of the wolf, a very powerful figure in Germanic culture, representing the looming threat of Bolshevism.

The murderous wolf's paws are covered in blood as it overlooks a man drowning in a pool of brightly colored red blood. Throughout northeastern Europe, tales of men who transform into wolves, or werewolves, have been present since the middle ages. In the $19^{\text {th }}$ century the famous German academics and folklore enthusiasts, Jacob and Wilhelm Grimm, also known the 'the brothers Grimm,' retold the story of Little Red Riding Hood, the story of a young girl confronted by a wolf, in their 1812, Kinder- und Hausmärchen (Children's and Household Tales). The imagery of the wolf would be regularly utilized in propaganda in WWII by the Nazi's. Hitler's own Eastern-Front military headquarters was called the Wolfsschanze, or 'Wolf's Lair.'

The poster, Kohle ist Brot, is another subtle appeal to the threat of Bolshevism. Here we see another grim German poster showing an image of a skeleton that obviously resembles the face of the Bolshevik leader, Vladimir Lenin. This picture shows Lenin, or at least an obviously 'Lenin-like' caricature reaching across the German industrial skyline from the great beyond stealing precious wheat as 3 German workers hopelessly idly look on. The phrase, Kohle ist Brot, translates in English to 'Coal is Bread.'

At one level, this clearly is an appeal to the German workers to do their patriotic duty to work and not strike or engage in any other subversive activities that might disrupt in the war effort. If coal is not being mined and refined, then there will be no bread. While this is obvious, the poster clearly is also insinuating that there exists a Bolshevik threat from beyond. This poster effectively conveys 2 separate messages; the importance of not engaging in labor stoppages and the dangers of the new emerging foreign ideology of Bolshevism. If the workers do not produce enough coal and remain patriotic, the evil new political movement from Russia will steal all the food and leave the German people starving.

\section{Conclusion}

The function of art has been debated amongst cultural critics and scholars pre-dating

Epiphany: Journal of Transdisciplinary Studies, Vol. 7. No. 2, (2014) (C) Faculty of Arts and Social Sciences 
Aristotle and Plato. (Wrigley, 1993, and Elkins, 1996) As mentioned in the introduction, while some critics would never accept that war propaganda art, is in fact, art, one cannot deny its practical importance in shaping norms and mores. This is especially true in the $20^{\text {th }}$ and into the $21^{\text {st }}$ centuries. According to Howard Lutz, "War-time propaganda obviously implies national education with an ulterior motive: the creation of new desires, group hypnosis, and isolation of counter propaganda, saturation of the public with selected and biased information (Lutz, 1933: 497)." As means of communication have advanced, so too has the implementation of propaganda.

This paper concludes that U.S. and German WWI propaganda art had some obvious similarities, but even more important differences. It is important to note that this paper is not meant to be an 'exhaustive study' of every image of propaganda that ever appeared in the US and Germany during WWI. Such an endeavor would most certainly be a very long book. However this paper did seek to offer a broad set of general hypotheses that can later be tested in future research projects by other scholars.

In regard to similarities; both nations sought to create posters that would appeal to emotion over reason. Each side utilized powerful imagery, often of women and children. These images were then coupled with short and simple instructions, such as 'buy war bonds' or 'serve your country bravely.' Some of the techniques used by the US in WWI, especially in regards to food rationing, were so successful, they were almost directly recycled in the posters the US used in WWII. "The same slogans - 'Food will win the war; don't waste it', 'Plant victory gardens to ensure victory', and 'Only buy what you can eat' - can also be found on posters from the early 1940s. These posters employ the same iconography, colour palette, and themes, and substitute one German leader for another (Hitler for the Kaiser) (Tunc, 2012: 216).” The Germans also recycled many of the same themes utilized in their WWI posters in their WWII posters.

Both sides also followed Chambers 3 main areas of content in regards to war propaganda art, not just in posters, but in other mediums of propaganda art as well The 3 themes mentioned by Chambers were; 1) appeals to the patriotism in an attempt to motivate civilians to contribute to the war effort by joining the military; 2) Appeals to civilian-orientated activities, emphasizing the civilian/military inter relationship and the role citizens can play at home to contribute to the war effort, and; 3) efforts to demonize the enemy in with the intent of instill hate and fear for the enemy in the citizens. (Chambers, 1983) The US utilized the newly emerging film industry to demonize the German enemy, while as shown in this article; the German's demonized Bolshevism in numerous different posters.

This paper has shown some important thematic and stylistic difference between German and US propaganda posters. In the American case, The Great War, was framed in

Epiphany: Journal of Transdisciplinary Studies, Vol. 7. No. 2, (2014) (C Faculty of Arts and Social Sciences 
a way that not only appealed to American patriotism, but also to individual self-interest. Many of the American posters sought to make the connection between military training and learning a skill or trade that could make money when the war was over. The colors used in the posters also differed. Many American posters utilized brighter colors than did the Germans, and regularly utilized smiling faces of children and images of industrious, happy women.

The image of Uncle Sam also became a useful marketing tool for the military during this time. Uncle Sam was an easily identifiable cartoonish figure that anyone; literate or illiterate; educated or uneducated; black or white; male or female could understand. The war was not as existentially dangerous to the United States as it was for Germany; even if the US lost, it would still most certainly maintain its sovereignty and freedom, even though its global aspirations of hegemonic power may have been temporarily halted. Once again, the fact that this war was not a matter of life or death for the nation as a whole, made convincing American's to fight even more difficult. Lutz quotes early $20^{\text {th }}$ century Canadian novelist and British politician, Sir Gilbert Parker as saying, "[The Americans] have nothing to gain by success in this war except something spiritual, mental, manly, national, and human. They are in this war because they believe German policy is a betrayal of civilization (Lutz, 1933: 514)." With this in mind, it is no surprise why American propaganda art sought to make the war experience seem less miserable and more hopeful.

In regards to the German case, the artwork in the posters is much more ominous and foreboding. The war was viewed by many Germans as a matter of life or death for the nation. This is reflected in the artwork. Perhaps the poster of distraught family best exemplifies the state of mind in Germany when the war broke out in 1914. The general color scheme of the German posters was much darker, and the themes were less hopeful than those utilized by the Americans. References to personal self-gain after the war were generally absent from German WWI propaganda artwork. As mentioned above, the German poster art seemed to focus more on demonizing enemies than American poster art. A common leitmotif that was often demonized was the threat of Bolshevism. This interesting to note because the Bolsheviks did not formally assume power in Russia until well after the war had ended. The threat of Bolshevism would be a central theme in World War II in German propaganda as well.

\section{References}

Adie, Katie. 2013. Fighting on the Home Front: The Legacy of Women in World War One. London: Hodder $\&$ Stoughton.

Adorno, Theodor. 2004. Aesthetic Theory. Ed. Gretel Adorno and Rolf Tiedemann. Translated by Robert Hullot-Kentor. New York: Continuum.

Banta, M. 1987. Imaging American Women: Idea and Ideals in Cultural History. New York: Columbia

Epiphany: Journal of Transdisciplinary Studies, Vol. 7. No. 2, (2014) (C Faculty of Arts and Social Sciences 
University Press.

Chambers, R. 1983. "Art and Propaganda in an Age of War: The Role of Posters." Scientia Militaria, South African Journal of Military Studies, 13(4): 54-59.

Daniel, U. 1997. The War from Within: German Working-Class Women in the First World War. New York: Berg Publishers.

DeBauche, L.M. 1997. Reel Patriotism: The Movies and World War I. Madison, WI: University of Wisconsin Press.

Dewey, D. 2007. The Art of Ill Will: The Story of American Political Cartoons. New York: NYU Press.

Dumenil, L. 2002. "Women and the Great War." OAH Magazine of History, 17(1): 35-39.

Elkins, James 1996. “Art Criticism,” In, Jane Turner (ed.), Grove Dictionary of Art. New York: Oxford University Press.

Fowle, Gates, et. al. 1918. "Extracts from Constantinople Committee's Report dated June 30, 1918," In, The American Committee for Relief in the Near East, its history, its work and the need for support as outlined by President Wilson and others (1918). Accessed Online, https://archive.org/ details/1123893upenn

Fromm, E. 1984. The Working Class in Weimar Germany: a Psychological and Sociological Study. Cambridge, MA: Harvard Press.

Gordon, M. 1999. 'Onward Kitchen Soldiers: Mobilizing the Domestic during WWI,' Canadian Review of American Studies, 29: 61-87.

Harrison, M. 1995. "The British Army and the problem of venereal disease in France and Egypt during the First World War." Medical History. 39(2): 133-158.

Houston, K. 2012. An Introduction to Art Criticism: Histories, Strategies, and Voices. New York: Pearson.

Hartcup, G. 1988. The War of Invention; Scientific Developments, 1914-18. London: Brassey's Defence Publishers.

Jones, Howard. 2001. Crucible of Power: A History of U.S. Foreign Relations Since 1897. New York: Rowman \& Littlefield.

Jünger, Ernst. 2004. Storm of Steel. Translated by Michael Hofmann. New York: Penguin Books.

Kingsbury, C. 2008. “"Food Will Win the War": Food and Social Control in World War I Propaganda,' In, K. LeBesco and P. Naccarato (eds.), Edible Ideologies: Representing Food and Meaning. Albany, NY: SUNY Press. pp. 37-52.

Kellner, Doug 2005. "Western Marxism," In, Austin Harrington (Ed.), Modern Social Theory: An Introduction. Oxford, UK: Oxford University Press. pp. 154-174.

Keith, J. 2004. Rich Man's War, Poor Man's Fight: Race, Class, and Power in the Rural South during the First World War I. Chapel Hill, NC: University of North Carolina Press.

Paul A. Kramer. 2011. "The Military-Sexual Complex: Prostitution, Disease and the Boundaries of Empire during the Philippine-American War." The Asia-Pacific Journal. 9(30) No. 2: 1-17. Accessed Online, http://japanfocus.org/-Paul_A_-Kramer/3574

Latham, J. 2006. "Technology and 'Reel Patriotism,' in American Film Advertising of the World War I Era." Film and History, 34: 36-43.

Lawrence, E.A. 1990. "Symbol of a Nation: The Bald Eagle in American Culture." The Journal of American Culture. 13(1): 63-69.

Epiphany: Journal of Transdisciplinary Studies, Vol. 7. No. 2, (2014) (C Faculty of Arts and Social Sciences 
Library of Congress Archives. "The Most Famous Poster." American Treasures of the Library of Congress. Accessed Online, http://www.loc.gov/exhibits/treasures/trm015.html

Lochimescu, O. and Tomford, J. 2014. "Tuberculosis," Cleveland Clinic Continuing Education Disease Management Project. Accessed Online, http:/www.clevelandclinicmeded.com/medicalpubs/ diseasemanagement/infectious-disease/tuberculosis/

Lossing, B. 1850. Pictorial Field Book of the Revolution, Volume II, Supplement XIV.

Lutz, R. H. 1933. "Studies of World War Propaganda, 1914-33," The Journal of Modern History, 5(4): 496-516.

Parker, [Sir] G. 1918. “The United States and the War,” Harper's Magazine, 138: 521-31.

Randolph, T.J. 1830. “Jefferson's Memoirs: Memoirs, Correspondence, and Miscellanies from the Papers of Thomas Jefferson." Southern Review, 5(9): 100-138.

Schulze, H. 1982. Weimar. Deutschland 1917-1933. Berlin: Severin u. Siedler.

Skees, Murray. 2011. "Kant, Adorno and the Work of Art." Philosophy and Social Criticism. 37(8): 915933.

Stanley, P. 1983. What Did You do in the War, Daddy? A Visual History of Propaganda Posters. New York: Oxford University Press.

Tunc, T.E. 2012. "Less Sugar, More Warships: Food as American Propaganda in the First World War," War in History, 19(2) 193-216.

Verhey, J. 2000. The Spirit of 1914: Militarism, Myth and Mobilization in Germany. Cambridge, UK: Cambridge University Press.

Williamson, S.H. 2014. "Seven Ways to Compute the Relative Value of a U.S. Dollar Amount, 1774 to present," MeasuringWorth.com. Accessed Online, http://www.measuringworth.com/uscompare/ relativevalue.php

Wrigley, James. 1993. The Origins of French Art Criticism: from the Ancien Régime to the Restoration. Oxford, UK: Clarendon Press.

Epiphany: Journal of Transdisciplinary Studies, Vol. 7. No. 2, (2014) (C Faculty of Arts and Social Sciences 